\title{
MINING
}

UDC 622.02 .112

S.F. Vlasov, orcid.org/0000-0002-5537-6342,

Ye. V. Moldavanov, orcid.org/0000-0002-6593-6462 https://doi.org/10.33271/nvngu/2021-6/016

Dnipro University of Technology, Dnipro, Ukraine, email: vlasov.s.f@nmu.one

\section{EFFECT OF GEOLOGICAL AND TECHNOLOGICAL PARAMETERS ON THE CONVERGENCE IN A STOPE}

Purpose. To study regularities in changes in convergence of wall rocks along a setting line of the powered props depending upon the sandstone availability within the roof, mining depth, as well as its position relative to the coal seam along the length of the extraction column based on the results of numerical experiments and forecast probable zones of rigid settlement of the powered support units according to a longwall length at any moment of a stope arrangement along the extraction pillar in accordance with changes in geological and technological parameters.

Methodology. The paper represents numerical experiments based upon 3D computer modelling of incremental stope advance within a layered transverse and isotopic rock mass while applying Solid Works Simulation 2019 software.

Findings. The research results, concerning the nature of wall rock distribution value within a stope, are given. The results were obtained using incremental computer modelling of the longwall advance within a layered transverse and isotopic rock mass within the area of initial caving of the main roof.

Originality. In the context of the Western Donbas mines, regularities of convergence value of wall rock distribution have been determined depending upon certain changes in such a system of geological and technological parameters as: availability of sandstone with 5 and $30 \mathrm{~m}$ thickness both within the immediate rock and at $30 \mathrm{~m}$ distance as well as nonavailability of sandstone within a roof; 215, 260 and $305 \mathrm{~m}$ changes in longwall length; 150, 300 and $450 \mathrm{~m}$ changes within a zone of initial caving of the main roof $(15-45 \mathrm{~m})$ with $10 \mathrm{~m}$ increment of longwall distancing from an installation chamber at $10-50 \mathrm{~m}$ distances.

Practical value. The identified regularities of changes in convergence value make it possible to forecast probable zones of rigid settlement of the powered support units depending upon the longwall length at any moment of a stope location along the extraction pillar irrespective of mining depth. The abovementioned helps optimize the parameters of seam extraction for the conditions of the Western Donbas mines if required.

Keywords: mining depth, longwall length, computer modelling, convergence, sandstone thickness, numerical experiments

Introduction. A stope advance as well as increase in the mined-out space dimensions results in the distribution of stressstrain state of the rock mass. Convergence of wall rocks is one of the manifestations of mine pressure. The convergence value along a setting line of hydraulic supports of the powered props is quite an important technological parameter since the line is the place and reason of rigid settlement of the units. In turn, the abovementioned prevents from the powered support advance. The matter is that a shearer holds covering of the powered props units; hence, there is no required path for the shearer to extract rock mass which creates emergency situation in the longwall. Comparison of changes in regularities of wall rock convergence along a line of hydraulic supports of the powered props with their allowable flexibility helps conclude that it is possible to apply one or another type or nominal size of the powered props under specific mining and technological conditions while forecasting probable zones of rigid settlement of the powered support units depending upon a longwall length at any moment of a stope location along an extraction pillar irrespective of mining depth.

Literature review. Paper by O. A. Sydelnykov [1] represents results of rock convergence analysis in a stope obtained using incremental computer modelling of the longwall advance within a layered transverse and isotopic rock mass.

Such researchers as V. I. Bondarenko and I. A. Kovalevska [2] have carried out numerical analysis with the help of a fi-

(C) Vlasov S. F., Moldavanov Ye.V., 2021 nite-element method to improve stope stability. Interconnection regularities between the rational operation parameters of props and the basic geomechanical factors, influencing heavily its load and reaction, have been determined.

Chinese scientists, headed by Ang Li [3], have performed complex study resulting in the development of elastic and plastic model to weaken and distribute support pressure. Moreover, a degree of mining depth influence on the support pressure value has been determined as well as its distance from a stope deep into the rock mass.

Group of Indian researchers, headed by Sreenivasa Rao Islavath [4], has analyzed convergence in a longwall and pressure development within hydraulic supports of the powered props before the main roof caving and after it, taking into consideration different degrees of its thickness, overhang length behind support, and rock type. For the purpose, 216 3D models were considered using finite-element method and involving Drucker-Prager yield criterion.

$\mathrm{Ze} \mathrm{Xia,} \mathrm{et} \mathrm{al.} \mathrm{[5]} \mathrm{represent} \mathrm{outcomes} \mathrm{of} \mathrm{numerical} \mathrm{studies}$ on stope stability as well as characteristics of dynamic development of vertical stresses and plastic condition of rock mass which help understand that transition from an elastic state to a plastic one results in significant deformations and dissociations. To provide safe stope operation, a combined method for roof control has been proposed.

Large-scale physical modelling experiment helped Chinese researcher Jinfu Lou [6] study gradual potential stress 
evolution stipulated by coal mining. Analysis of the results demonstrated that trajectories of the basic stresses are arched. The experiment achieved high accuracy between the field observations and results of physical modelling; hence, the physical model recorded realistic reaction of upper layers.

Based upon numerical modelling and field observation, the paper by Guojun Zhang [7] studied the evolution of rock mass stress over a seam roof. It was concluded that the process of stress recovery after the main roof caving is of periodic steplike increment nature, and the roof over the mined-out space is broken layer-by-layer.

Jun Lu and Changbao Jiang [8] carried out a large-scale 3D experiment with a physical similarity model as well as numerical modelling to test reliability of the physical model. In this context, characteristics of strain fields and rock mass breaking, resulted from coal seam extraction, were analysed.

Indian scientists [9] studied a mechanism of unstable behaviour of the main roof during coal seam mining as well as the associated lamination. The abovementioned was applied as the basis for project criteria to evaluate safe operation of a stope.

Chinese scientists [10] have demonstrated field research on the main roof response during the longwall advance. The data helped conclude that depth variation is the key factor of changes in stress range within the rock mass resulting from coal mining. The deeper coal occurrence is, the greater range of stress changes is.

The abovementioned papers involved neither the integrated effect of sandstone occurrence parameters as a separate lithological system nor the changes in longwall length and the stope distancing from an installation chamber when it is in the area of initial caving of the main roof.

Our research is focused on the factors.

Purpose. It is required to study regularities of changes in the value of wall rock convergence along a landing line of the powered support risers depending upon the sandstone availability within a roof, longwall length, mining depth as well as its location in terms of the extraction pillar based upon the results of incremental simulation of the stope advance within a spatial computer model of the laminated transversal and isotropic rock mass; it is also required to forecast probable zones of rigid settlement of the powered support units in terms of stope location along the extraction pillar irrespective of mining depth.

Methods (structure, order). The paper proposes additional combination of such new characteristics within the available studies [1] as the stope length, stope distancing from an installation chamber, sandstone thickness value, and its occurrence spacing above a seam roof as paper [11] has substantiated them.

SolidWorks 2019 software was applied for 225 computer experiments with various geological and technological parameters for the Western Donbas mines carried out in accordance with the experimentation schedule [11].

The model geometry was determined depending upon the changes in such three parameters as stope length, distancing from an installation chamber, and mining depth. Physicomechanical characteristics were assumed in accordance with the data in [1]. Sandstone occurrence above a seam roof was assumed in accordance with the experimentation schedule [11].

Finite element network was assumed as a standard one. Maximum linear size of the finite element was taken up as $5 \times 0.5 \mathrm{~m}$ [11]. Taking into consideration the fact that the model has one symmetrical plane, passing normally to the central part of the stope, mathematical calculations were performed only for one symmetrical section [1]. For the purpose, the required boundary conditions within edge parts of the model were held as well as within the symmetry plane. The effect of a stope support was simulated by means of the distributed resistance to the seam roof and floor preset near the location of lines of the powered support risers [1]. The geometry of resistance setting area corresponded to the geometry of the powered support of 1 КД- 80 type. The distance was $2.5 \mathrm{~m}$ from the stope face; two lines with $0.1 \times 1.0 \times 215 \mathrm{~m}, 0.1 \times 1.0 \times$ $\times 260 \mathrm{~m}$, and $0.1 \times 1.0 \times 305 \mathrm{~m}$ dimensions were applied. Roof resistance was specified as $2.5 \mathrm{MPa}$; floor resistance was specified as 3.0 MPa [1].

The simulation involved a zone of initial caving of the main roof (15-45 m); and the simulated stope distancing from an installation chamber was $10,20,30,40$, and $50 \mathrm{~m}$ [11]. The simulation approach made it possible to consider incrementally the processes of stress-strain state redistribution within the rock mass making scientific meaning more important as well as practical utility of the results.

Results. Analysis of earlier studies showed that sandstone influence on the convergence value within a longwall as a separate lithological subsystem is understudied right in the context of computer modelling of the stope advance along the extraction pillar. Among other things, there are no regularities on convergence value distribution; the fact complicates absolutely the optimization of rational parameters of coal seam mining within the area.

To analyse sandstone influence of convergence value distribution, the findings are summarized in Table 1.

Analysis of the simulation results showed that if sandstone occurs within a seam roof or if it is not available there, a convergence value may experience 6.6 times' variation. However, the value is minor, thus, having no influence on rigid settlement of the powered support units. The difference between the experiments, involving sandstone occurrence above a seam roof and ignoring it, is $2.7-18.0 \mathrm{~mm}$. Let us exemplify it in terms of the experiments (Fig. 1) where thickness of sandstone, occurring in the immediate roof, is $30 \mathrm{~m}$ and maximum convergence is $143.3 \mathrm{~m}$ : if sandstone with $30 \mathrm{~m}$ thickness occurs $30 \mathrm{~m}$ over the seam roof, then maximum convergence value is $146.0 \mathrm{~mm}$; hence, depending upon the changes in sandstone parameter consideration, minimum difference is $2.7 \mathrm{~mm}$.

Maximum $18.0 \mathrm{~mm}$ discrepancy of the convergence values is seen after the experimentation (Fig. 2). Maximum convergence value, being $500.0 \mathrm{~mm}$, is observed if sandstone is not available within the immediate roof. If sandstone with $30 \mathrm{~m}$

Table 1

Difference in the convergence values

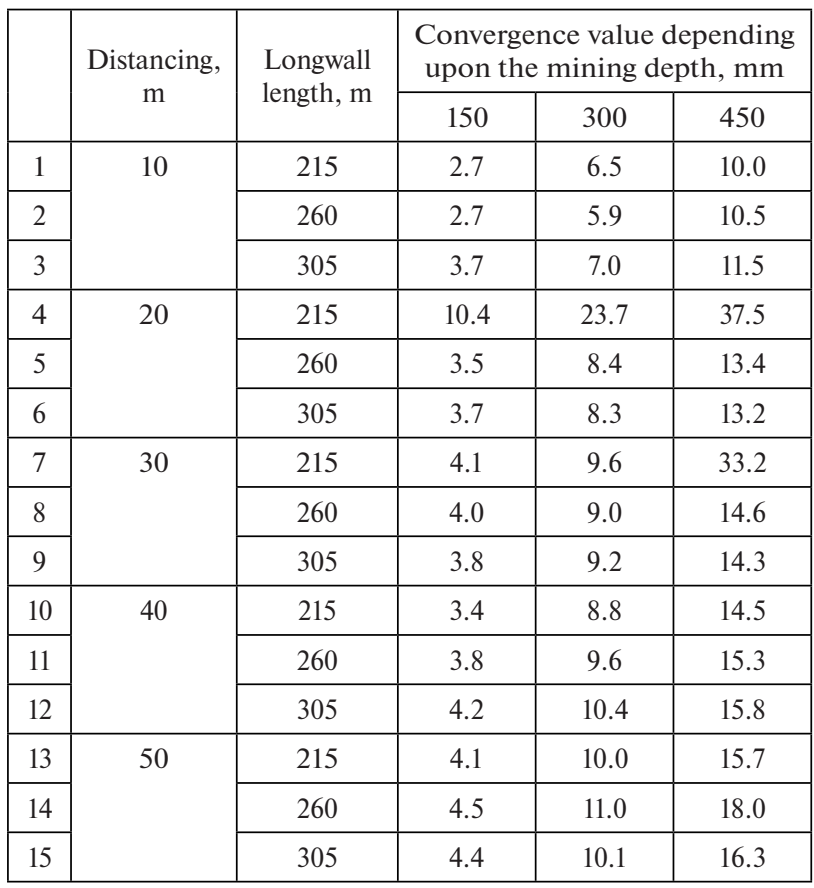




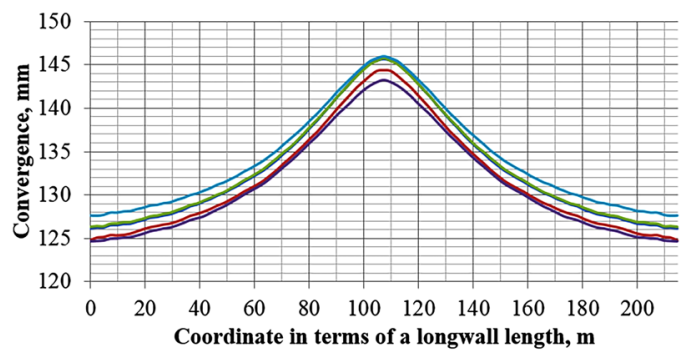

- No sandstone

- Sandstone with $5 \mathrm{~m}$ thickness occurring within the immediate roof - Sandstone with $5 \mathrm{~m}$ thickness occurring $30 \mathrm{~m}$ over the seam roof

- Sandstone with $30 \mathrm{~m}$ thickness occurring within the immediate roof - Sandstone with $30 \mathrm{~m}$ thickness occurring $30 \mathrm{~m}$ over the seam roof

Fig. 1. Nature of the convergence value distribution within a longwall if its distancing from an installation chamber is $10 \mathrm{~m}$; the longwall length is $215 \mathrm{~m}$; mining depth is $150 \mathrm{~m}$

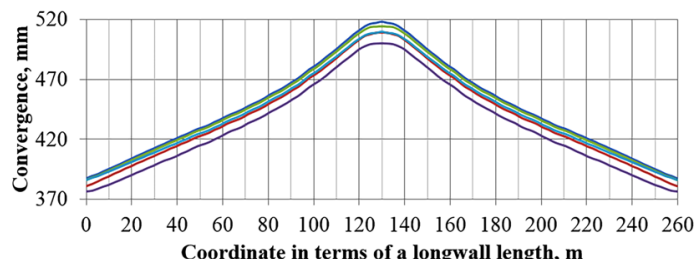

-No sandstone

- Sandstone with $5 \mathrm{~m}$ thickness occurring within the immediate roof - Sandstone with $5 \mathrm{~m}$ thickness occurring $30 \mathrm{~m}$ over the seam roof -Sandstone with $30 \mathrm{~m}$ thickness occurring within the immediate roof

-Sandstone with $30 \mathrm{~m}$ thickness occurring $30 \mathrm{~m}$ over the seam roof

Fig. 2. Nature of a convergence value distribution within a longwall if its distancing from an installation chamber is $50 \mathrm{~m}$; the longwall length is $260 \mathrm{~m}$; mining depth is $450 \mathrm{~m}$

thickness occurs within the immediate roof, then maximum convergence value is $518.0 \mathrm{~mm}$, i. e. depending upon the changes in the sandstone consideration, the discrepancy is $18.0 \mathrm{~mm}$.

To compare with the Central Donbas mines, minor discrepancy between the convergence values depending upon the changes in the parameters if sandstone is taken into consideration can be explained by the fact that interaction with such low-rank minerals as aleurite and argillite, resulted from the stress, is compensated owing to the physicomechanical characteristics of the mentioned rocks. Hence, no significant difference in the rock mass stress of the main roof in the Western Donbas mines was identified despite the expectations.

Another thing is that the effect of thick sandstone can be observed in the neighbourhood of a stope where it influences the formation of higher stresses to compare with the mentioned sandstone nonavailability (Figs. 3-5).

So, if sandstone does not occur within a seam roof, then stress value in the neighbourhood of a stope is 112.0$83690.0 \mathrm{MN} / \mathrm{m}^{2}$. The value of a zone of stress propagation, where disturbances are shown in green, being 27970.0 $62800.0 \mathrm{MN} / \mathrm{m}^{2}$, is $2.35 \mathrm{~m}$ in front of a stope deep into the rock formation; $1.75 \mathrm{~m}$ above the seam roof; and $1.80 \mathrm{~m}$ below the seam floor (Fig. 3).

If sandstone with $30 \mathrm{~m}$ thickness occurs within the immediate roof, then stress value around the stope is 237.0$89370.0 \mathrm{MN} / \mathrm{m}^{2}$. The value of a zone of stress propagation, where disturbances are shown in green, being 29 950.0$67090.0 \mathrm{MN} / \mathrm{m}^{2}$, is $2.25 \mathrm{~m}$ in front of a stope deep into the rock formation; $2.40 \mathrm{~m}$ above the seam roof; and $1.95 \mathrm{~m}$ below the seam floor (Fig. 4).

If sandstone with $30 \mathrm{~m}$ occurs $30 \mathrm{~m}$ above a seam roof, then stress value around the stope is $68.0-83880.0 \mathrm{MN} / \mathrm{m}^{2}$. The value of a zone of stress propagation, where disturbances are shown in green, being $28000.0-62920.0 \mathrm{MN} / \mathrm{m}^{2}$ is $2.30 \mathrm{~m}$ in front of a stope deep into the rock formation; $1.90 \mathrm{~m}$ above the seam roof; and $1.70 \mathrm{~m}$ below the seam floor.

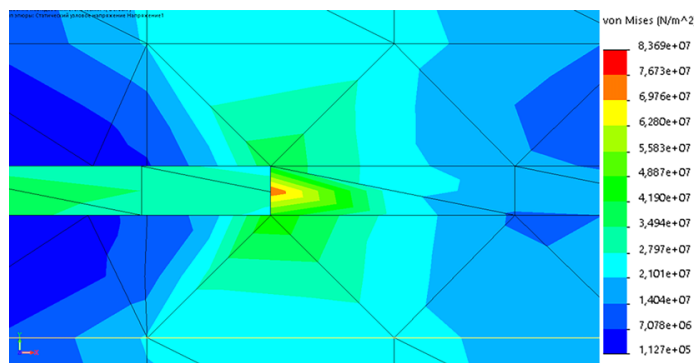

Fig. 3. Distribution of the stress values of rock formation around a stope if its distancing from an installation chamber is $50 \mathrm{~m}$; longwall length is $305 \mathrm{~m}$; mining depth is 450; sandstone within the roof is not taken into consideration

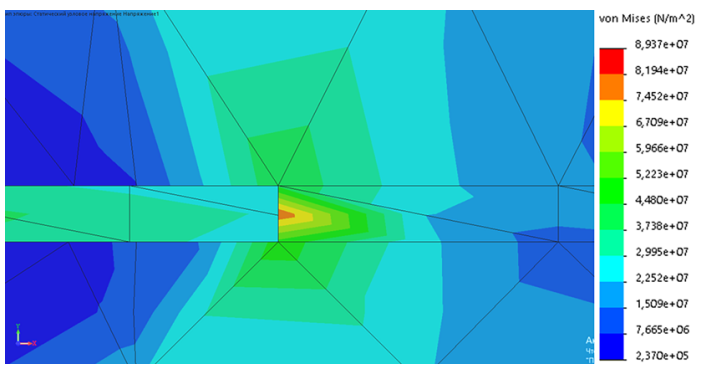

Fig. 4. Distribution of the stress values of rock formation around a stope if its distancing from an installation chamber is $50 \mathrm{~m}$; longwall length is $305 \mathrm{~m}$; mining depth is 450; sandstone with $30 \mathrm{~m}$ thickness is available in the immediate roof

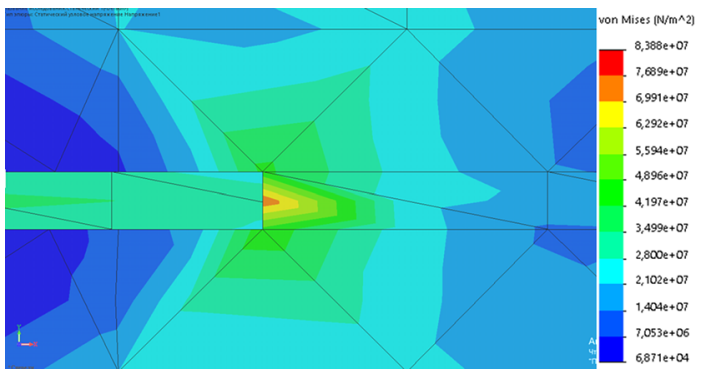

Fig. 5. Distribution of the stress values of rock formation around a stope if its distancing from an installation chamber is $50 \mathrm{~m}$; longwall length is $305 \mathrm{~m}$; mining depth is 450; sandstone with $30 \mathrm{~m}$ thickness occurs $30 \mathrm{~m}$ above the seam roof

Taking into consideration changes in the sandstone parameters, the listed processes are observed during all the experiments if mining depths are $15,300,450 \mathrm{~m}$, and length of stopes are 215, 260, $305 \mathrm{~m}$.

Consider changes in the convergence value depending upon the changes in stope distancing as well as involving the mining depth (Table 2).

The analysis of the modelling results showed that within the area of initial caving of the main roof, convergence value increases along with both mining depth and stope distancing from an installation chamber (Table 2).

Table 2 helps conclude the following. Distancing by $10 \mathrm{~m}$ from an installation chamber and each $100 \mathrm{~m}$ deepening result in 88.4-89.4 increase in maximum convergence value in the central share of a longwall. The increase is 92.2-92.5 $\mathrm{mm}$ in terms of $20 \mathrm{~m}$ distancing; $97.0-97.6 \mathrm{~mm}$ in terms of $30 \mathrm{~m}$ distancing; $103.2-103.9 \mathrm{~mm}$ in terms of $40 \mathrm{~m}$ distancing; and $110.3-112.3 \mathrm{~mm}$ in terms of $50 \mathrm{~m}$ distancing. In this context, the maximum convergence value varies within the range of $88.4-112.3 \mathrm{~mm}$ according to the changes in distancing as well as according to the changes in mining depth. 
Table 2

Maximum changes in the convergence value relative to the parameter changes

\begin{tabular}{|c|c|c|c|c|c|}
\hline & \multirow{2}{*}{$\begin{array}{l}\text { Distancing, } \\
\mathrm{m}\end{array}$} & \multirow{2}{*}{$\begin{array}{c}\text { Stope } \\
\text { length, } \mathrm{m}\end{array}$} & \multicolumn{3}{|c|}{$\begin{array}{l}\text { Convergence value relative to } \\
\text { the mining depth, } \mathrm{mm}\end{array}$} \\
\hline & & & 150 & 300 & 450 \\
\hline 1 & \multirow[t]{3}{*}{10} & 215 & 145.8 & 278.5 & 411.0 \\
\hline 2 & & 260 & 146.3 & 278.9 & 413.5 \\
\hline 3 & & 305 & 146.1 & 280.0 & 414.5 \\
\hline 4 & \multirow[t]{3}{*}{20} & 215 & 151.2 & 289.4 & 427.8 \\
\hline 5 & & 260 & 151.1 & 289.4 & 427.8 \\
\hline 6 & & 305 & 151.5 & 289.8 & 429.0 \\
\hline 7 & \multirow[t]{3}{*}{30} & 215 & 159.0 & 304.5 & 450.1 \\
\hline 8 & & 260 & 159.1 & 305.3 & 451.6 \\
\hline 9 & & 305 & 159.1 & 305.6 & 452.0 \\
\hline 10 & \multirow[t]{3}{*}{40} & 215 & 167.8 & 322.5 & 477.5 \\
\hline 11 & & 260 & 169.3 & 325.0 & 481.0 \\
\hline 12 & & 305 & 170.5 & 326.6 & 483.3 \\
\hline 13 & \multirow[t]{3}{*}{50} & 215 & 178.4 & 344.0 & 509.5 \\
\hline 14 & & 260 & 181.1 & 350.0 & 518.0 \\
\hline 15 & & 305 & 182.0 & 350.0 & 518.7 \\
\hline
\end{tabular}

Fig. 6 demonstrates the nature of the convergence value distribution depending upon the increased stope distancing from an installation chamber if longwall length is $215 \mathrm{~m}$ and mining depth is $150 \mathrm{~m}$; sandstone occurrence within the roof is ignored.

Fig. 6 helps understand that in the central share of a longwall when depth is $150 \mathrm{~m}$ and distancing from an installation chamber is $10 \mathrm{~m}$, maximum convergence value is $145.8-$ $146.3 \mathrm{~mm}$. If the distancing is $20 \mathrm{~m}$, then the value increases by $5.2-5.3 \mathrm{~mm}$, achieving $151.1-151.5 \mathrm{~mm}$. In terms of $30 \mathrm{~m}$, the increase is $7.6-7.9 \mathrm{~mm}$, achieving $159.0-159.1 \mathrm{~mm}$; in terms of $40 \mathrm{~m}$, the increase is $8.8-11.4 \mathrm{~mm}$, achieving $167.8-$ 170.5; and in terms of $50 \mathrm{~m}$, the increase is $10.6-11.5 \mathrm{~mm}$, achieving $167.8-170.5 \mathrm{~mm}$. In this context, relative to distancing changes, maximum convergence value varies within the range of $145.8-170.5 \mathrm{~mm}$. Hence, the difference is $24.7 \mathrm{~mm}$. On average, each $10 \mathrm{~m}$ of the longwall advance within the initial caving of the main roof results in $6.5-7.1 \mathrm{~mm}$ increase in the convergence value.

Fig. 7 demonstrates the nature of the convergence value distribution depending upon the increase in stope distancing from an installation chamber if longwall length is $215 \mathrm{~m}$; mining depth is $300 \mathrm{~m}$; sandstone is not taken into consideration.

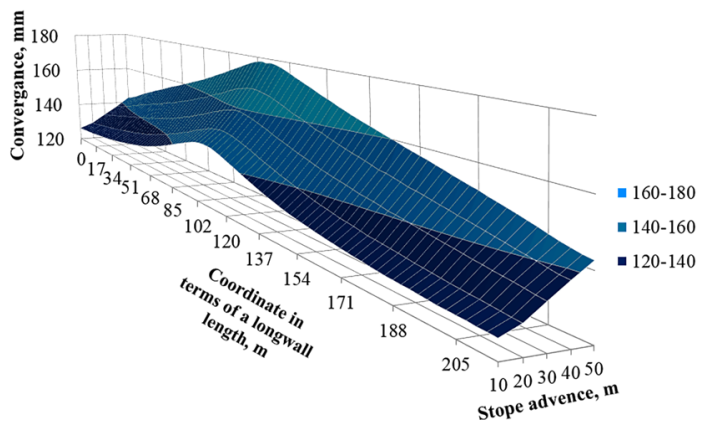

Fig. 6. Nature of the convergence value distribution depending upon the increase in stope distancing from an installation chamber if longwall length is $215 \mathrm{~m}$; mining depth is $150 \mathrm{~m}$; sandstone is not taken into consideration

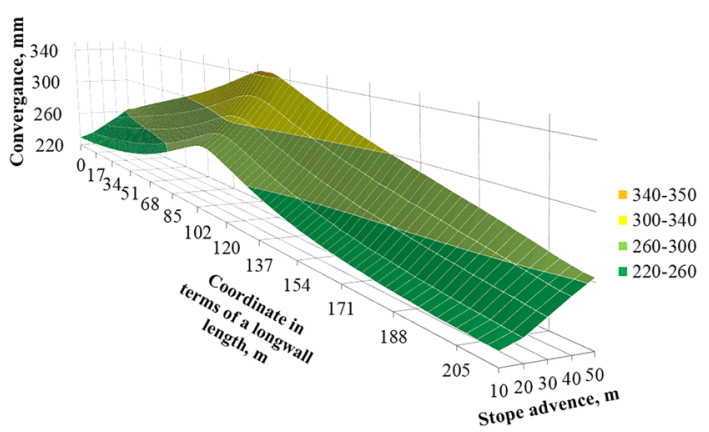

Fig. 7. Nature of the convergence value distribution depending upon the increase in stope distancing from an installation chamber if longwall length is $215 \mathrm{~m}$; mining depth is $300 \mathrm{~m}$; sandstone is not taken into consideration

According to Fig. 7, maximum convergence value within the central longwall share at $10 \mathrm{~m}$ distancing from an installation chamber is $278.5-280.0 \mathrm{~mm}$. The increase is $9.8-$ $10.9 \mathrm{~mm}$ (i. e. up to $289.4-289.8 \mathrm{~mm}$ ) if distancing is $20 \mathrm{~m}$. If distancing is $30 \mathrm{~m}$, the increase is $15.1-15.8 \mathrm{~mm}$ (i. e. up to $304.5-305.6 \mathrm{~mm}$ ). Consequently, $18.0-21.0 \mathrm{~mm}$ increase (i. e. up to $322.5-326.6 \mathrm{~mm}$ ) takes place if distancing is 40 and $50 \mathrm{~m}$ distancing results in $21.5-24.0 \mathrm{~mm}$ increase (i.e. up to $344.0-350.0 \mathrm{~mm})$. In this regard, depending upon the distancing changes, maximum convergence value varies within the range of $278.8-350.0 \mathrm{~m}$. The difference is $71.2 \mathrm{~mm}$. On average, each $10 \mathrm{~m}$ of the longwall advance within the initial caving of the main roof results in 13.1-14.0 $\mathrm{mm}$ increase in the convergence value.

Fig. 8 explains the nature of the convergence value distribution depending upon the increase in stope distancing from an installation chamber if longwall length is $215 \mathrm{~m}$; mining depth is $450 \mathrm{~m}$; sandstone is not taken into consideration

According to Fig. 8, maximum convergence value within the central longwall share at $10 \mathrm{~m}$ distancing from an installation chamber is $411.5-414.5 \mathrm{~mm}$. The increase is $14.5-$ $16.3 \mathrm{~mm}$ (i.e. up to $427.8-429.0 \mathrm{~mm}$ ) if distancing is $20 \mathrm{~m}$. If distancing is $30 \mathrm{~m}$, the increase is $22.3-23.0 \mathrm{~mm}$ (i.e. up to $450.1-452.0 \mathrm{~mm}$ ). Consequently, $27.4-31.3 \mathrm{~mm}$ increase (i. e. up to $450.1-452.0 \mathrm{~mm}$ ) takes place if distancing is 40 and $50 \mathrm{~m}$ distancing results in 32.0-35.4 mm increase (i. e. up to 509.5$350.0 \mathrm{~mm}$ ). In this regard, depending upon the distancing changes, maximum convergence value varies within the range of $411.5-518.7 \mathrm{~mm}$. Thus, the difference is $107.2 \mathrm{~mm}$. On average, each $10 \mathrm{~m}$ of the longwall advance within the initial caving of the main roof results in 19.6-20.8 $\mathrm{mm}$ increase in the convergence value.

Consider a problem where dependence of the convergence value distribution takes place relative to changes in a stope length. As it follows from Table 2, discrepancy between $215 \mathrm{~m}$ longwall length and $305 \mathrm{~m}$ one at $150 \mathrm{~m}$ depth and $10 \mathrm{~m}$ dis-

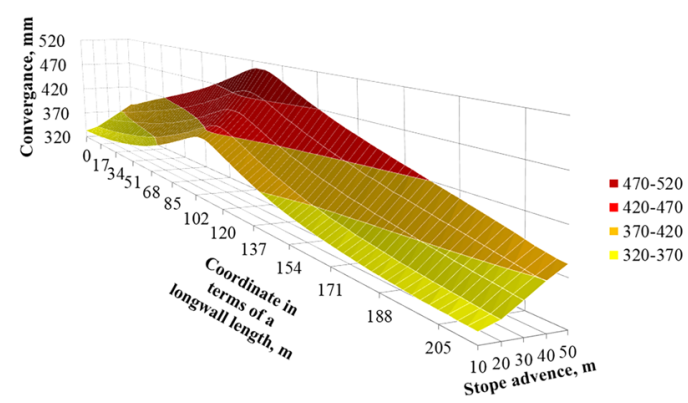

Fig. 8. Nature of the convergence value distribution depending upon the increase in stope distancing from an installation chamber if longwall length is $215 \mathrm{~m}$; mining depth is $450 \mathrm{~m}$; sandstone is not taken into consideration 
tancing will be $0.5 \mathrm{~mm} .20 \mathrm{~m}$ distancing will result in $0.4 \mathrm{~mm}$; $30 \mathrm{~m}$ distancing will result in $0.1 \mathrm{~mm} ; 40 \mathrm{~m}$ distancing will result in $2.7 \mathrm{~mm} ; 50 \mathrm{~m}$ distancing will result in $3.6 \mathrm{~mm}$ discrepancy.

If mining depth is $300 \mathrm{~m}$, the convergence value is $1.5 \mathrm{~mm}$ in terms of $10 \mathrm{~m}$ distancing; $0.4 \mathrm{~mm}$ in terms of $20 \mathrm{~m}$ distancing; $1.1 \mathrm{~mm}$ in terms of $30 \mathrm{~m}$ distancing; $4.1 \mathrm{~mm}$ in terms of $40 \mathrm{~m} ; 6.0 \mathrm{~mm}$ in terms of $50 \mathrm{~m}$.

Difference in the convergence values between $215 \mathrm{~m}$ longwall length and $305 \mathrm{~m}$ length in terms of $450 \mathrm{~m}$ depth and $10 \mathrm{~m}$ distancing is $3.5 \mathrm{~mm}$. It is $1.2 \mathrm{~mm}$ in terms of $20 \mathrm{~m}$ distancing; $1.9 \mathrm{~mm}$ in terms of $30 \mathrm{~m}$ distancing; $5.8 \mathrm{~mm}$ in terms of $40 \mathrm{~m}$ distancing; $9.2 \mathrm{~mm}$ in terms of $50 \mathrm{~m}$ distancing.

The abovementioned makes it possible to state that the change in a stope length influences insignificantly the convergence value in a longwall. For instance, $215 \mathrm{~m}$ longwall length as well as $305 \mathrm{~m}$ one results in $0.1-9.2 \mathrm{~mm}$ convergence value. Thus, discrepancy is $9.1 \mathrm{~mm}$.

Comparison with actual conditions demonstrates such an interesting regularity: in the Western Donbas mines, mining depth is followed by stope length. The fact support correctness of the modelling results as well as the selection of length values to carry out the research (Fig. 9).

It should also be noted that the research findings have helped forecast the initial caving of the main roof, which occurred in terms of availability of sandstone with $5 \mathrm{~m}$ thickness occurring at $150 \mathrm{~m}$ depth within the immediate roof when longwall length is $215 \mathrm{~m}$ and distancing is $20 \mathrm{~m}$. After the main roof caving, unloading of the powered support units as well as $175 \mathrm{~mm}$ down to $140 \mathrm{~mm}$ convergence reduce is observed (Fig. 10).

Reliability testing (Fig. 10) should involve such a note that the initial caving of the main roof took place in Pavlohradska mine (Pavlohradske MA) within longwall 121 where $C_{1}$ seam was extracted in 2020-2021. The caving increment was $21.5 \mathrm{~m}$ in terms of $154 \mathrm{~m}$ mining depth, and $220 \mathrm{~m}$ longwall length. Sandstone with $16.6 \mathrm{~m}$ thickness occurred at 6.7-15.8 distance above the seam roof.

Moreover, initial caving of the main roof occurred. It took place with $5 \mathrm{~m}$ thickness sandstone occurrence in the immedi-

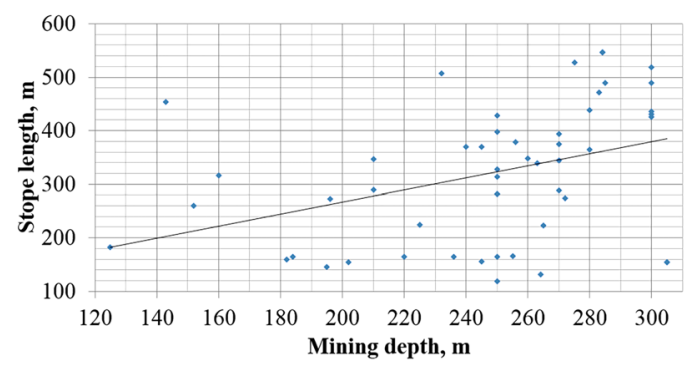

Fig. 9. Statistical analysis of the stope length and depth

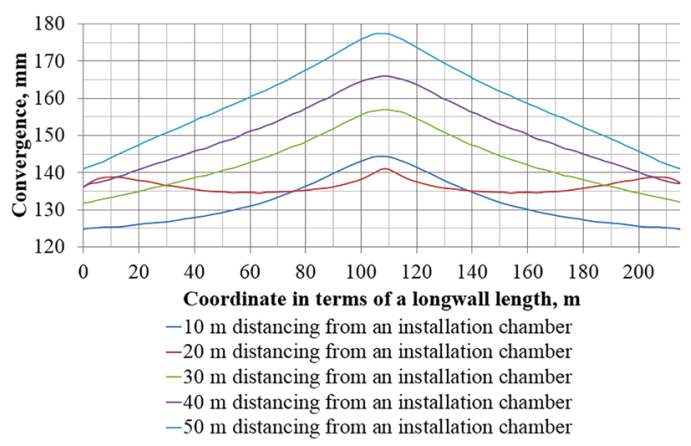

Fig. 10. Initial caving of the main roof at $20 \mathrm{~m}$ stope distancing from an installation chamber. Longwall length is $215 \mathrm{~m}$; mining depth is $150 \mathrm{~m}$; sandstone with $5 \mathrm{~m}$ thickness occurs within the immediate roof ate roof at $300 \mathrm{~m}$ depth. Longwall length was $215 \mathrm{~m}$; and distancing was $20 \mathrm{~m}$. After the main roof caving, unloading of the powered support units is recorded as well as convergence decrease in the longwall from 500 down to $410 \mathrm{~mm}$ (Fig. 11).

To validate the results (Fig. 11), similar conditions of the initial caving of the main roof were represented. The caving occurred in Heroiv Kosmosu mine (Heroiv Kosmosu MA). Longwall 958 was involved where $\mathrm{C}_{9}$ seam was extracted in 2018-2019. The caving increment was $23.5 \mathrm{~m}$; mining depth was $300 \mathrm{~m}$; and longwall length was $245 \mathrm{~m}$. Sandstone occurred at $5.7 \mathrm{~m}$ distance; its thickness was $7.4 \mathrm{~m}$.

The research findings have also helped identify initial caving of the main roof which took place under sandstone occurrence with $5 \mathrm{~m}$ thickness. In turn, the sandstone occurs within the immediate roof at $450 \mathrm{~m}$ depth in terms of $215 \mathrm{~m}$ longwall length and $20 \mathrm{~m}$ distancing. After the main roof caving, unloading of the powered support units is recorded as well as convergence decrease in the longwall from 500 down to $390 \mathrm{~mm}$ (Fig. 12).

To validate the results (Fig. 12), similar conditions of initial caving of the main roof were represented. The caving occurred in Zakhidno-Donbaska mine (Ternivske MA). Longwall 1039 was involved where $C_{10}$ seam was extracted in 2019-2020. The caving increment was $27.0 \mathrm{~m}$; mining depth was $450 \mathrm{~m}$; and longwall length was $285 \mathrm{~m}$. Sandstone occurred at $7.3 \mathrm{~m}$ distance; its thickness was $4.0 \mathrm{~m}$.

In addition, one of the experiments helped forecast the initial caving of the main roof, observed in terms of the sandstone availability. Its thickness is $30 \mathrm{~m}$; its occurrence is $30 \mathrm{~m}$ above the seam roof. The initial caving of the main roof results in the decreased height of a working space and roof rock shearing along a stope line. Moreover, a shearer turns out to be clamped by the cover of the powered support units; there is no required path for the shearer to drive through and operate (Fig. 13).

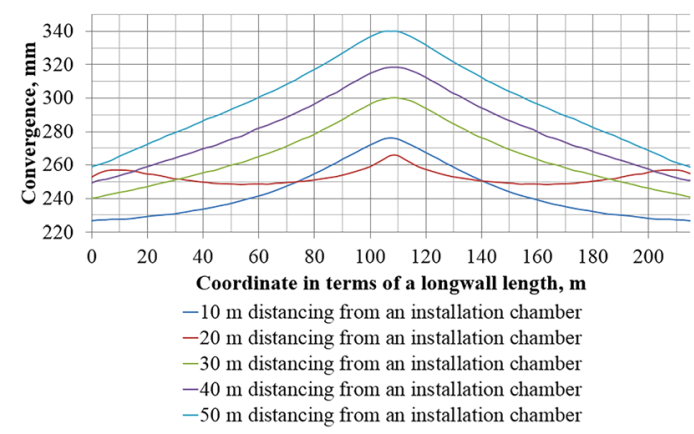

Fig. 11. Initial caving of the main roof in terms of $20 \mathrm{~m}$ stope distancing from an installation chamber. Longwall length is $215 \mathrm{~m}$; mining depth is $300 \mathrm{~m}$; sandstone with $5 \mathrm{~m}$ thickness occurs within the immediate roof

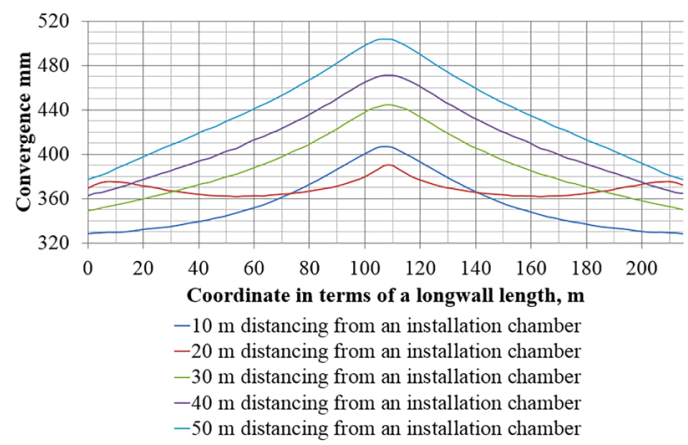

Fig. 12. Initial caving of the main roof when the stope distancing from an installation chamber is $20 \mathrm{~m}$; longwall length is $215 \mathrm{~m}$; mining depth is $450 \mathrm{~m}$; sandstone with $5 \mathrm{~m}$ thickness occurs within the immediate roof 


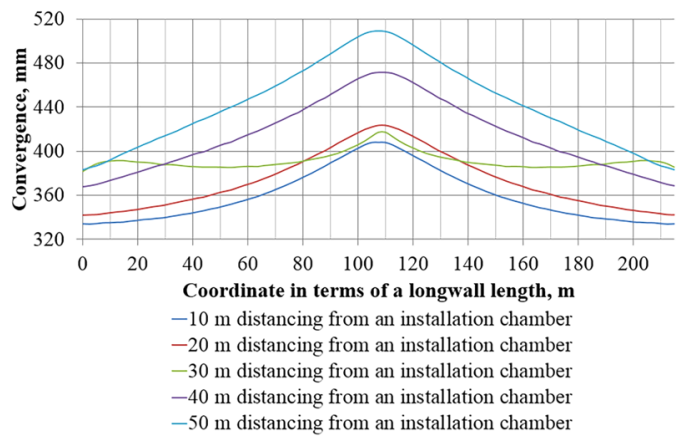

Fig. 13. Initial caving of the main roof when the stope distancing from an installation chamber is $20 \mathrm{~m}$; longwall length is $215 \mathrm{~m}$; mining depth is $450 \mathrm{~m}$; sandstone with $30 \mathrm{~m}$ thickness occurrence $30 \mathrm{~m}$ above the seam roof

To validate the results (Fig. 13), similar conditions of the initial caving of the main roof were represented. The caving occurred in Zakhidno-Donbaska mine (Ternivske MA). Longwalls $863,865,881$, and 883 were involved where $C_{8}$ seam was extracted in 2019-2020. The caving increment was 30.0$40.0 \mathrm{~m}$; mining depth was 419-483 m; and longwall length was 275-300 m. Sandstone occurred at $14.0-17.0 \mathrm{~m}$ distance; its thickness was $0-8.7 \mathrm{~m}$. It is also possible to introduce a comparative example concerning extraction of $C_{10}$ seam by means of longwalls 1039 and 1041 in 2019-2021. The caving increment was 27.0-38.0 m; mining depth was $419 \mathrm{~m}$; and longwall length was $285-300 \mathrm{~m}$. Sandstone occurred at $7.3 \mathrm{~m}$ distance; its thickness was $0-14.1 \mathrm{~m}$.

When longwall 128 of $C_{6}$ seam was being extracted in $Y u$ vileina mine (Pershotravenske MA), initial caving of the main roof occurred at $25 \mathrm{~m}$ distance. Mining depth was $428 \mathrm{~m}$; longwall length was $143 \mathrm{~m}$; sandstone with $2.8-12.2$ thickness occurred $14.7 \mathrm{~m}$ above the seam roof.

When longwall 159 of $C_{6}$ seam was being extracted in Stepova mine (Pershotravenske MA), the initial caving of the main roof occurred at $27.5 \mathrm{~m}$ distance. Mining depth was $391 \mathrm{~m}$; longwall length was $283 \mathrm{~m}$; sandstone with $0-2.5$ thickness occurred $17.2 \mathrm{~m}$ above the seam roof.

As for the forecasting of accidents connected with rigid settlement of the powered support units, it is possible to say that the experiments identified such a situation at $450 \mathrm{~m}$ depth only irrespective of sandstone occurrence within the roof when a stope is distancing from an installation chamber within the area of the main roof initial caving. Difference between accidents is as follows: length of a zone of rigid settlement of the units varied (Table 3 ).

Conclusions. Analysis of the simulation results has shown that irrespective of sandstone occurrence within the seam roof, a convergence value may experience 6.6 times' variation. However, the value is not significant, thus, having no influence on rigid settlement of the powered support units. To compare with the Central Donbas mines, minor discrepancy between the convergence values depending upon changes in the parameters if sandstone is taken into consideration can be explained by the fact that interaction with such low-rank minerals as aleurite and argillite, resulted from the stress, is compensated owing to physicomechanical characteristics of the mentioned rocks. Hence, no significant difference in the rock mass stress of the main roof in the Western Donbas mines has been identified despite the expectations. Another thing is that the effect of thick sandstone is observed in the neighbourhood of a stope where the sandstone influences formation of higher stresses to compare with the mentioned sandstone nonavailability.

The study helped obtain the values of rock mass stress distribution in the neighbourhood of a stope under different conditions.

Certain changes in the convergence values, depending upon the changes in the stope distancing and taking into ac-
Table 3

Length of a zone of rigid settlement of the powered support units depending on changes in the parameters at $450 \mathrm{~m}$ depth

\begin{tabular}{|c|c|c|c|}
\hline & $\begin{array}{l}\text { Distancing, } \\
\mathrm{m}\end{array}$ & $\begin{array}{c}\text { Stope length, } \\
\mathrm{m}\end{array}$ & $\begin{array}{l}\text { Length of the units } \\
\text { settlement zone, m }\end{array}$ \\
\hline 1 & \multirow[t]{3}{*}{10} & 215 & $5-19$ \\
\hline 2 & & 260 & $5-24$ \\
\hline 3 & & 305 & $9-25$ \\
\hline 4 & \multirow[t]{3}{*}{20} & 215 & $27-41$ \\
\hline 5 & & 260 & $30-44$ \\
\hline 6 & & 305 & 29-49 \\
\hline 7 & \multirow[t]{3}{*}{30} & 215 & $27-81$ \\
\hline 8 & & 260 & $64-88$ \\
\hline 9 & & 305 & $63-91$ \\
\hline 10 & \multirow[t]{3}{*}{40} & 215 & $105-135$ \\
\hline 11 & & 216 & $122-166$ \\
\hline 12 & & 305 & $141-199$ \\
\hline 13 & \multirow[t]{3}{*}{50} & 215 & $156-181$ \\
\hline 14 & & 260 & $196-226$ \\
\hline 15 & & 305 & $243-285$ \\
\hline
\end{tabular}

count mining depth, have been considered. Analysis of the modelling results has shown that within the area of initial caving of the main roof, a convergence value increases both along with mining deepening and with the stope distancing from an installation chamber.

It should also be mentioned that changes in a stope length have minor influence of a convergence value within the longwall.

Four cases of initial caving of the main roof were forecasted during the experiment.

The research findings were validated while comparing the experimental data with the recorded technical data by the Western Donbas mines.

The regularities of convergence distribution nature make it possible to forecast probable zones of rigid settlement of the powered support units according to a longwall length at any moment of stope location along the extraction pillar irrespective of mining depth.

\section{References.}

1. Vlasov, S. F., \& Sydelnykov, A. A. (2012). Spatial modeling of geomechanical processes in underground mining. Dnipropetrovsk: National Mining University. ISBN: 978-966-350-348-6.

2. Bondarenko, V.I., Kovalevska, I.A., Symanovych, G.A., Sotskov, V.A., \& Barabash, M.V. (2018). Geomechanics of interference between the operation modes of mine working support elements at their loading. Mining Science, (25), 219-235. https://doi.org/10.5277/ msc182515.

3. Ang, L., Qiang, M., Li, M., Li, K., Qian, M., \& Jianbo, C. (2020). Coal Mine Abutment Pressure Distribution Based on a Strain-Softening Model. Frontiers in Physics, 8(263), 1-15. https://doi.org/10.3389/ fphy. 2020.00263

4. Sreenivasa, R. I., Debasis, D., \& Hemant, K. (2020). Development of a roof-to-floor convergence index for longwall face using combined finite element modelling and statistical approach. International Journal of Rock Mechanics and Mining Sciences, 127, 36-45. https://doi. org/10.1016/j.ijrmms.2020.104221.

5. Ze, X., Qiang, 1. Y., Guosheng, M., Qiang, X., Chuanjin, T., Liu, Z., ..., \& Qian, S. (2021). Numerical study of stability of mining roadways with $6.0-\mathrm{m}$ section coal pillars under influence of repeated mining. International Journal of Rock Mechanics and Mining Sciences, 138, 139-144. https://doi.org/10.1016/j.ijrmms.2021.104641.

6. Jinfu, L., Fuqiang, G., Jinghe, Y., Yanfang, R., Jianzhong, L., Xiaoqing, W., \& Lei, Y. (2021). Characteristics of evolution of min- 
ing-induced stress field in the longwall panel: insights from physical modeling. International Journal of Coal Science \& Technology, (1), 1-18. https://doi.org/10.1007/s40789-020-00390-5.

7. Guojun, Z., Quansheng, L., Yong, Z., \& Feng, D. (2021). Failure characteristics of roof in working face end based on stress evolution of goaf. Geomechanics and Geophysics for Geo-Energy and Geo-Resources, 7(53), 18-30. https://doi.org/10.1007/s40948-021-00252-7.

8. Jun, L., Changbao, J., Zhuo, J., Wensong, W., Wanjun, Z., \& Huan, Y. (2021). Three-dimensional physical model experiment of mining-induced deformation and failure characteristics of roof and floor in deep underground coal seams. Process Safety and Environmental Protection, 150, 400-415. https://doi.org/10.1016/j.psep.2021.04.029. 9. Behera, B., Yadav, A., Singh, G. P., \& Sharma, S. K. (2020). A numerical modeling approach for evaluation of spalling associated face instability in longwall workings under massive sandstone roof. Engineering Failure Analysis, 117, 225-236. https://doi.org/10.1016/j.Engfai lanal.2020.104927.

10. Dychkovskyi, R., Shavarskyi, I., Saik, P., Lozynskyi, V., Falshtynskyi, V., \& Cabana, E. (2020). Research into stress-strain state of the rock mass condition in the process of the operation of double-unit longwalls. Mining of Mineral Deposits, 14(2), 85-94. https://doi. org/10.33271/mining 14.02.085.

11. Vlasov, S. F., \& Moldavanov, Y.V. (2021). Substantiation of parameters of the experiment with three-dimensional computer modeling of the rock mass around a longwall. Journal of Donetsk Mining Institute, (1), 1-13. https://doi.org/10.31474/1999-981x-2021-1-37-48.

\section{Вплив геолого-технологічних параметрів на конвергенцію в очисному вибої}

\section{С. Ф. Власов, С.В. Молдаванов}

Національний технічний університет «Дніпровська політехніка», м. Дніпро, Україна, e-mail: vlasov.s.f@nmu.one

Мета. Дослідити закономірність зміни величини конвергенції бічних порід уздовж посадкового ряду стояків механізованого кріплення залежно від наявності пісковиків у покрівлі, глибини розробки, довжини лави, а також його положення відносно вугільного пласта за довжиною виїмкового стовпа на підставі результатів виконання чисельних експериментів. Спрогнозувати ймовірні зони посадки секцій механізованого кріплення «на жорстку базу» за довжиною лави, у будь-який момент положення очисного вибою вздовж виїмкового стовпа на будь-якій глибині розробки, залежно від зміни геологотехнологічних параметрів.

Методика. У роботі наведені чисельні експерименти, що базуються на тривимірному комп'ютерному моделюванні покрокового посування очисного вибою в шаруватому трансверсально-ізотропному масиві гірських порід шляхом застосування програмного продукту Solid Works Simulation 2019.

Результати. Наведені результати дослідження характеру розподілу величини конвергенції бічних порід в очисному вибої, що були отримані з використанням покрокового комп'ютерного моделювання посування лави в шаруватому трансверсально-ізотропному масиві гірських порід у зоні первинної посадки основної покрівлі.

Наукова новизна. В умовах шахт Західного Донбасу встановлені закономірності характеру розподілу величини конвергенції бічних порід у лаві залежно від зміни комплексу геолого-технологічних параметрів, таких як: наявність пісковиків потужністю 5 та 30 м як у безпосередній покрівлі, так і на відстані 30 м, а також відсутність пісковиків у покрівлі, зміни довжини очисного вибою 215,260 та 305 м, глибини розробки 150,300 та 450 м у зоні первинної посадки основної покрівлі (15-45 м) із кроком відходу лави від монтажної камери 10 м на відстані від 10 до $50 \mathrm{M.}$

Практична значимість. Виявлені закономірності зміни величини конвергенції дозволять спрогнозувати ймовірні зони посадки секцій механізованого кріплення «на жорстку базу» за довжиною лави в будь-який момент положення очисного вибою вздовж виїмкового стовпа на будь-якій глибині розробки, i, за необхідності, у зв'язку з цим, оптимізувати параметри відпрацювання вугільних пластів для умов шахт Західного Донбасу.

Ключові слова: глибина розробки, довжина лави, комп'ютерне моделювання, конвергенція, потужність пісковику, чисельні експерименти

The manuscript was submitted 02.04.21. 